\title{
THE ROLE OF TERMS OF CREATIVE ENGAGEMENT IN STUDENTS' SELF-STUDY IN FOREIGN LANGUAGE CLASSES IN HIGHER EDUCATION
}

\author{
E. Dorofeeva,
}

Assoc. Prof. Dr., Kazan Federal University, Russian Federation, elena.dor@mail.ru

\begin{abstract}
The present research reveals the significance of applying students' self-studywhich is defined asself-directed learningin the article, using terms of creative engagements to master a fluent foreign language in higher education institutions. It is noted that the creative tasks (terms of creative engagements) contribute to the increase of the cognitive interest in learning foreign languages and obtaining a deeper knowledge in this sphere. The author describes and analyzes varieties of terms of creative engagementsin students' selfstudy,independent and individual work,researches the features and effectiveness of the application of such assignments in order to improve the quality of teaching and acquiring a higher level of mastering knowledge of a foreign language, as well as the issue of the relevancyto control over the implementation of students' self-study, self-directed learningactivities by a teacher. The purpose of the present article is to show that the most effective way to obtain in-depth knowledge of foreign languages is to increase the share of terms of creative engagements in self-study,self-directed learning,that form the student's creative potential, contribute to the development of their cognitive forces and abilities, their creative self-development, increase their interest in a foreign language. The tasks of the paper are to consider and analyze terms of creative engagements (creative assignments), to determine among them the most suitable and productive ones to involve students in self-study of a foreign language at a higher school to obtain a deeper language knowledge, as well as to designate pedagogical requirements for the application of creative tasks in learning languages on their own and to pay attention to the control over the implementation of this work by a teacher and self-control by students themselves. The author also provides examples of the terms of creative engagements being used in foreign language classes at the university. The ideas behind the article can be used for the development of the main pedagogical principles of application ofanalyze terms of creative engagements(creative tasks) in students' self-study,self-directed learning,in foreign language classes and the development of various types and instructions on application of these tasks taking into account the level of the foreign language proficiency.
\end{abstract}

Keywords: students' self-study, self-directed learning, foreign language, students, creative tasks, assignments

\section{INTRODUCTION}

Modern society developing presupposes the search for new optimal forms and methods of university education. Introduction of the competent approach in training assumes deepening and expansion of students' knowledge and also formation students' interest to cognitive activity, mastering methods of 
scientific knowledge, achievement of high level of self-consciousness and development of ability to reflection in educational process.

Mastering these techniques is impossible without effective organization of students' self-study, independent work. Effectively organized independent work not only contributes to the formation of professional competence, but also provides the process of developing methodological skills, skills for self-organization and self-control of educational activities. This is especially important as it implies the formation of a future specialist as a subject matter of professional activity capable of self-development, designing and reforming his or her actions [8].

When it comes up with foreign languages, universities currently face the demand to provide students with good knowledge of a foreign language by applying effective, optimal forms and methods of teaching aimed at developing their need for continuous self-improvement and self-development in the learning languages.

Nowadays, it is possible to deeply master foreign languages in higher education institutions not only in classes, but also through the effective organization of students' self-study, self-directed learning and skillful combination of different types and forms of work, the use of creative (active) tasks in self-study, that contribute to a deeper learning of a foreign language, promote creative students'self-development.

Hence, there is a need to use as many creative tasks as possible in self-study work, since they (students), solving the functions of developing education, form the creative potential, contribute to the development of their cognitive forces and abilities, increase interest in foreign languages and theirworking knowledge is improving, becoming deeper and more mobile. It is creative tasks that require students to have a creative attitude towards learning. It is necessary to remember that to create is to discover something new or create something more perfect, fundamentally new, still unknown. It is proved in the psychological and pedagogical literature that a student, who has enjoyed of the own search and creativity undoubtedly, has a great interest and respect for the creative activity of other people, for the mastering of spiritual values, for the results of the generations'creativity [1, p.96].

\section{METHODS}

The following methods were used in the research: 1. the theoretical methods which are related to the literature searches, namely, such methods as compilation of the bibliography. It is the list of the references which have been chosen according to the researched problem. The next one is abstracting that is a concise text of the main content of one or several studies in general subjects. Summarizing is taking of more detailed records the basis of which is to sum up the main ideas and cases of research. Annotating is a short record of the general contents of a book or an article. Citing is a literal record of expressions which are actual or digital data given in the reference. 2. Theoretical analysis is highlighting and reviewing of specific features, characteristics of the phenomena. Having analyzed definite facts, classified and systematized them, we have revealed general and special features in them, set a general principle or rule. The analysis was followed by synthesis that helped to understand the subject matter of the phenomena studied. 3 . The inductive and deductive methods are logical methods of generalization of the empirical data obtained. Due to the inductive method we have assumed the conception progress from the private opinions to the general output and from a general opinion to a personal conclusion by means of the deductive method. 4. A comparative method allowed us to set similarities and differences between objects and the phenomena. 5. Analysis and synthesis. The analysis has let to clarify which parts the studied object consists of and synthesis has let to connect the parts received when analyzing into integral. As a result, there was a connection of knowledge gained while analyzing in a single system. 6 . Research and synthesis of pedagogical experience of teachers at higher education institutions and teachers of schools directed to the analysis of a status of practice, developing of the best practices.

\section{RESULTS}

A creative task/assignment is an educational task containing a creative component for the solution of which aand student has to use knowledge, techniques or methods of solution that have never been applied before [7, p.195].

Applying such tasks repeatedly teaches students to constantly think and search for different options for their performance that contributes to the development of their creative imagination. According to I.Y. Lerner, the use of creative assignments promotes the acquiring of the creative activityexperience where a shift in the mental development of students occurs. It is expressed in the creative transformation of knowledge and skills, readiness and ability to independently obtain new ones that means to organize their cognitive activity in accordance with the problem encountered [5, p.87]. 
Creative assignments in foreign language classes, we believe, should always encourage students to become independent. It is in this case that they will allow students to experience the pleasure of intellectual work, to test their strength, to find their own solution in the process of concentrated, leisurely work, when they manage to discover new sides in the already known, when unexpected ideas, associations arise, mobilize creative imagination, guessing, intuition, fantasy, when they manage to express themselves.

According to M.A. Danilov, B.P. Esipov, the essence of any creative task, creative work consists of the complete learner's independence who creates something new on the basis of knowledge acquired by him/her; creates own ideas or realizes the idea set by the teacher, reveals it by the power of his/her imagination and active thinking. And since creative activity is an integral part of the learning process, the teacher's task is to teach students to work hard and creatively [2, p.335].

Using creative tasks in class has another very important point. Creative assignments in terms of their content and methods or techniques approach situations that may arise in the life of each person. The didactic goal of creative tasks, according to a number of authors, is to form students' ability to successfully navigate in life, the process of work, clearly, correctly and quickly solve problems through the creative application of knowledge and acquired skills. They distinguish between two levels of creative tasks. The first is characterized by the fact that their performance requires only a certain restructuring of the known things. The second level is distinguished by a large degree of creativity when the tasks doing with the introducing of new content elements or ways of doing things. Successful accomplishing of such assignments is characterized by the highest degree of digestion of skills and abilities [3, p.90].

In our lessons we use creative tasks of the first and second levels keeping in mind that almost any learning task can be presented in a creative form. The following assignments have a creative feature in our classes: reports, student'sresearch paper at seminars and conferences, inventing tasks and exercises, making up questions, finding additional information on the topic under study, participating in a role-playing game, reviewing a self-reading work, making a plan for the topic, written analysis of a fiction text, etc. However, the greatest creativity in foreign language lessons contains such types of training tasks as a project protection and dramatization. Such activities stimulate independent/individual search, which is very important for us, although they cause more difficulties than other tasks. Thus, we use the assignments - projects that are quite widespread in studying abroad, cause students to ask questions, activity aimed at finding the necessary tools and materials.

German scientists, attaching great importance to the students' self-study/self-directed learning, believe that project-based learning is the most effective way to achieve this goal. They emphasize that students should be actively involved both in the planning, organization and execution of the project and in the assessment of the results. However, the success of this training method depends largely on the psychological climate in the group as well as the relationship between teachers, research tutors and students. I. Kähler writes that the advantages of project-based learning are that "this form of training guarantees the student greater selfactivity, self-determination, and problem-based learning" [4, p.38].

Our experience shows project tasks are highly appreciated by students. They like to work independently, on their own and creatively. Having chosen a topic for the research, the student leans into the literature, collects material out of the library and, in consultation with the tutor, draws up the workby a certain date. It can be noted that the true benefit to students is only those activities that are related to life and carried out with great relish.

The tasks requiringmuch self-study and creativity also include staging/dramatization (passages of works, dialogues, etc.). B.T. Likhachev calls such a method 'the method of artistic performance', which is applicable to all subjects, and is being presented in the expressive expression of thoughts, reading by heart, declamation, competent singing, in the use of the rules of composition and technical methods of drawing, aesthetic performance of tasks, in the culture of work, the aesthetics of movements and behavior [6, p.472].

The teaching functionis valuable for us due to the developing effect and the educational importance of dramatization. The teaching function is to deepen students' knowledge of the material under study, to teach them to gain an aesthetic insight of phenomena, to express their ideological and emotional attitude to life, and to creatively design the results of their work. The developing effect is presented in the activation of students' aesthetic perception, creative imagination, the ability of artistic and imaginative thinking, in enriching their personality by means of artistic expression of themselves in behavior and work. The educational value lies in the formation of students' artistic taste, immunity against tastelessness and vulgarity [6, p.472-473].

It should also be mentioned that whatever creative tasks are used by the teacher in the foreign language 
classes, all of them allow to satisfy both cognitive, moral and aesthetic needs of students, thanks to the teacher'sability to introduce elements of creativity in the educational cognition, the possibility of a variety of instruments of the educational process to strengthen its cognitive and creative direction. It is possible with the help of the following tasks: setting up and solution of cognitive tasks of a searching type; performance of tasks of research character; search, comparison and analysis of different sources of scientific, educational information; tasks for creative processing, generalization and systematization of educational material; tasks for composition of compositions for classes-dramatizations, preparation for staging, reading by roles; tasks related to the performance of the role in the conditions of creative play in the class, etc.

The application of creative tasks while students' self-study, self-directed learning, in foreign language classes implies the fulfillment of certain pedagogical requirements. The most important requirements for us are:

1. Self-study, self-directed learning, with the use of creative tasks should be purposeful. Clear instructions should be stated to achieve the purpose of this type work. The teacher is to find a formulation of the creative task offered to students that would arouse their interest when working and desire to perform it as well as possible. Explaining of the assignments and the ways to check its implementation is important in organizing self-study process. Students should be clear about what their task is and how it will be assessed. This makes the students'work purposeful and contributes to more conscious performance.

2. Self-study work should be really independent; the students should think work hard when performing it. However, here we should not allow extremes: the content and scope of self-study activity should be feasible for studentsoffered at each stage of learning.

3. To make self-study contribute to the formation of students'initiative and cognitive abilities it is necessary to offer creative tasks for self-directed learning that would not allow actions on ready-made samples. Selflearning achieves the goal when doing it encourages students to apply previously obtained theoretical knowledge to the solution of the tasks.

4. The creative tasks offered for self-study should be of interest to students. Interest to do work stimulates the development of students' creative activity. It is achieved by the novelty of the proposed tasks, their unusual content, disclosure to students of the practical meaning of the proposed task or methods to be mastered.

Creative tasks in foreign language classes always involve some kind of actions with the language material, related to the introduction of new elements (changing, addition, etc.) or semantic processing of the material, which also involves a certain language work, but where the language form is subordinate to the content. Herewith, too, students will always lack the vocabulary that most fully and accurately conveys a thought for independent, spontaneous and proactive expression. In this case, the teacher, when choosing creative tasks to be used, should take into account that these tasks also contribute to the activation of lexical material. For this purpose, as practice shows, there should be as many creative tasks in foreign language classes as possible since it is these assignments that contribute to the firm consolidation of many skills and abilities.

It should not go unnoticed the fact that any self-study activity is based on the research work and search, it serves to activate the reserve students'capacity, acquaints them with research activities, inculcates such important skills as information search, identification of the main idea, assessment of the stated material.

It is very important, in our opinion, to stimulate scientific search by students. Incentives to scientific work are not only the satisfaction that students receive from the creative work of thought, but also various forms of moral reward: awarding certificates, diplomas for the best work, awarding small commemorative prizes (books, albums), etc..

We attach great importance to students' self-control and teacher's control in the course of their self-studying.

Self-control, self-monitoring,while self-studying is its component, a means of regulation, correction, and improvement of the ways of its performance, and therefore we try to involve students themselves (through consultations with the teacher, classmates) in the process of control, in turn carrying out a systematic, continuous control of the progress and outcome of self-study, because self-made tasks, as well as any type of work, must be checked and assessed by the teacher. The control, as well as moral encouragement, is an incentive for students, increases their interest in the performance of tasks, and allows them to achieve the desired results in the study of various topics in foreign language classes. Therefore, for the purpose of continuous feedback, constant control of independent work, we believe it is necessary to involve students in the activities of self-control and mutual control. 
In our opinion, it is essential to use self-study work as often as possible, especially with the creative assignments in foreign language classes in higher education institutions. It was mentioned in the academic literature, it is especially important not only because it prepares students for self-study after the compulsory course of study, but also because of their motivational potentials: nothing inspires self-confidence as the consciousness that the student has done the work him/herself, without the others' help.

\section{CONCLUSIONS}

Thus, we can state that it is necessary to use self-study, self-directed learning, both in and out-of-classesin order to master the high level of a foreign language at higher education institutions. The role of creative assignmentsis greatthat contribute to the in-depth mastering of a foreign language. In the course of such work, skills, taste for creative approach in educational, scientific and practical work of students are formed by means of personal searches and active interest in acquisition of knowledge, students'creative abilities, their creative potential are also developed and their aspiration for creative self-development is strengthened. Creative tasks allow to satisfy simultaneously cognitive, moral and aesthetic needs of students, promote activation of lexical material and firm fixation of many skills and abilities. That is why the share of creative tasks in the students' self-study work in foreign language lessons should be highest possible, because such tasks, based on the recreating imagination, activity of thinking processes, bring something original to the results of work, and, therefore, to a greater extent, develop the independence of the students. After all, no knowledge obtained on the level of passive perception, which has not become the object of one's own mental or practical work, can replace those thorough and practical skills that are acquired by self-studying.

\section{REFERENCE LIST}

1. Gordeeva N.A. Pedagogical stimulation of self-developing of students' creative imagination: Diss. Cand of Ped.science / N.A. Gordeeva; Kazan State University. - Kazan, 1996. - 16 p.

2. Danilov M.A. Didactics / M.A. Danilov, B.P. Esipov. - M.: Academy of Pedagogical Science, 1957. - 518 p.

3. Modern School Didactics: Course for Teachers / B.S. Kobzar, G.F. Kumarina, Yu.A. Kusyj and others. 1987. $-351 \mathrm{p}$.

4. Kehler J. Didaktik eines Studienreformmodells. - Verlag: Weinheim und Basel Beltz, 1973. - 212 S.

5. Lerner I.Ya. Didactics bases of traing methods / I.Ya. Lerner. - M.: Pedagogika, 1981. - 186 p.

6. Lihachyov B.T. Pedagogics: Lectures / Course book for students of Teachers' training Institutes. $-4^{\text {th }}$ edition / B.T. Lihachyov. - M.: Yurajt, 2000. - 523 p.

7. Pedagogics: Pedagogical theories, systems and techniques: coursebook for students of Institutes and Colleges / S.A. Smirnov, I.B. Kotova, E.N. Shiyanovi dr. - 4-e izd. - M.: «Academy», 2001. - 512 p.

8. Petrova L.A., Berestneva E.V., Brigadin A.A. Organization of students' self-study work according to Federal Educational Standard // Modern Issues of Science and Education. - 2015. - № 2-1. - URL: http://www.science-education.ru/ru/article/view?id=19211 